\title{
SEASONAL VARIABILITY OF CARBON MONOXIDE (CO) IN THE AMBIENT ENVIRONMENT OF IMO STATE, NIGERIA
}

\author{
Njoku Pascal ${ }^{1 a}$, *Ibe Francis Chizoruo ${ }^{1,2 b}$, Alinnor Jude ${ }^{1 c}$ and Opara Alex ${ }^{3 d}$ \\ ${ }^{1}$ Department of Chemistry, Federal University of Technology P.M.B. 1526, \\ Owerri, Imo State Nigeria \\ ${ }^{2}$ Department of Chemistry, Imo State University P.M.B 2000, Owerri, Imo State Nigeria \\ ${ }^{3}$ Department of Geology, Federal University of Technology 1526, Owerri, Imo State Nigeria

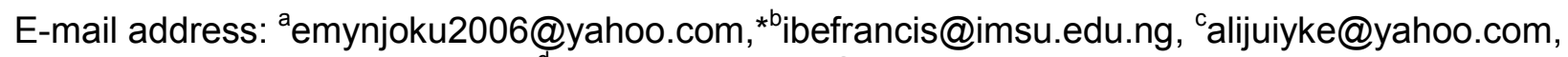 \\ oparazanda2001@yahoo.com
}

Keywords: Carbon monoxide, air pollutant, ambient, environment, variability.

\begin{abstract}
The air qualities of four areas in Imo State with a total of twenty two locations were monitored for a period six months with respect to $\mathrm{CO}$ level using Gasman air monitor (Crowcon Instruments Ltd, England. The air quality monitoring was conducted in the morning, afternoon and evening hours within dry and wet seasons in order to elucidate the variability of this atmospheric pollutant in the study locations. The results obtained showed significant variation of the air pollutant in the morning, afternoon and evening including within the twenty four weeks, and between dry and wet seasons. The mean values of $\mathrm{CO}$ in the dry season are in the order Egbema $>$ Okigwe $>$ Owerri $>$ Orlu, while the order for the mean $\mathrm{CO}$ level in wet season is Okigwe $>$ Orlu $>$ Egbema $>$ Owerri. Elevated concentration of $\mathrm{CO}$ was observed in the study areas above $10 \mathrm{ppm}$, the Nigerian National ambient air quality standard. This observation calls for health and environmental concern. Hence, anthropogenic activities and fugitive emission sources of atmospheric pollutants such as increased vehicular traffic, biomass combustion, use of electric power generating sets, leakages from incinerators and flare stacks should be seriously monitored.
\end{abstract}

\section{Introduction}

Pollution of the ambient environment is a serious environmental challenge that has posed significant threat to clean air, a basic and fundamental requirement of human existence and environmental health [1,2,3]. Human exposure to air pollutants is unavoidable in today's perspective especially in the urban areas of most developing countries [4], which has been associated with increased morbidity and mortality [5,6]. Though, air pollution could be due to natural sources [7]. A major anthropogenic source of atmospheric pollution is due to man's quest for a better standard of living, utilizing the natural resources for rapid industrialization and urbanization, consequently causing excessive air pollution [8]. This therefore could influence the tendency for the release of toxins to the environment [9], which increases the overall toxic burden of the environment [10]. Atmospheric pollution has continued to attract a lot of attention worldwide because of its negative effects on human health and well-being [11,12,13].

Carbon monoxide (CO) is an important trace gas which plays a significant role in the chemistry of most tropospheric reactions $[14,15]$. CO is poisonous and it affects the oxygencarrying capacity of the hemoglobin, could reduce mental health, and may eventually lead to death [16]. It contributes to greenhouse gas that warm the atmosphere [17,18]. Natural sources of CO emissions include oxidation of natural hydrocarbons and methane, emissions from ocean and vegetation. While the anthropogenic sources include combustion of fossil fuel and biomass, industrial activities and motor vehicles [19,20].

$\mathrm{CO}$ which has a lifetime of about four months in the ambient environment [17,21] is believed to be removed from the atmosphere by its reaction with hydroxyl radical, $\mathrm{HO}^{\circ}$, as in Eq. 1 - $2[17,21]$, the atomic hydrogen, $\mathrm{H}$, produced in Eq. 1 combines with oxygen molecule in the 
presence of a third body $(\mathrm{M})$ like $\mathrm{N}_{2}$ to form hydroproxyl radical. The photochemical reactions are also linked to the formation of ozone as shown in Eq. $3-5$ [22,23].

$$
\begin{aligned}
& \mathrm{CO}+\mathrm{HO}^{\bullet} \longrightarrow \mathrm{CO}_{2}+\mathrm{H} \\
& \mathrm{O}_{2}+\mathrm{H}+\mathrm{M} \longrightarrow \mathrm{HOO}^{\bullet}+\mathrm{M} \\
& \mathrm{HOO}^{\cdot}+\mathrm{NO} \longrightarrow \mathrm{HO}^{\cdot}+\mathrm{NO}_{2} \\
& \mathrm{NO}_{2}+\mathrm{UV} \text { radiation } \longrightarrow \mathrm{NO}+\mathrm{O} \\
& \mathrm{O}+\mathrm{O}_{2}+\mathrm{M} \longrightarrow \mathrm{O}_{3}
\end{aligned}
$$

The result of this is more than two million premature deaths each year, attributable to the effects of urban outdoor and indoor air pollution as reported by World Health Organization, and these effects are more prominent in developing countries [24], and Imo State, a part of Nigeria is not an exception. $\mathrm{CO}$ has been associated with mortality due to suffocation and poisoning [25]. It was reported that in the months of May and June, 2008 Nigeria recorded about 22 deaths resulting from CO poisoning [26].

Seasonal variation of atmospheric pollutants especially $\mathrm{CO}$ is an important factor in determining the ambient concentration of these pollutants which may vary from one location to the other due to pollution composition [27,28], and ability of the atmosphere to either absorb or disperse these pollutants [29]. In Nigeria, there are two distinct seasons, dry and wet seasons which could vary the atmospheric pollutants significantly. For instance, during dry season when the relative humidity is moderately low with higher wind velocity, pollutants have higher tendency of being swiftly dispersed than during the wet season [21]. Fluctuations in time of the seasons and difference in the ambient temperature, relative humidity and wind speed including wind direction could also vary the concentration of atmospheric pollutants over the seasons [30]. Abdul-Wahab and Bouhamra reported maximum concentrations of non-methane hydrocarbon, $\mathrm{CO}$, and NOx in the winter period and minimum concentrations in the summer period in Kuwait [31]. Also higher values of $\mathrm{SO}_{2}$ and $\mathrm{CO}$ concentrations in winter have been reported [32,33]. On the other hand increase in the concentration of atmospheric pollutant in late summer have also been reported, which was attributed to low wind speed, high temperature and subsidence inversion [34] .

The need for this study is necessitated by the fact that the population of Imo State stood at $3,934,899$ according to 2006 census [35], which must have increased significantly after ten years. The state have oil wells with enormous natural gas associated with them, which has a rough estimated reserve of about 1422 billion cubic meters, part of which has been continuously flared [36,37]. The use of power generators, high volume of vehicular traffic and presence of two stroke engine automobiles like motorcycles and tricycle used for transportation in most parts of the State known for incomplete combustion which could lead to increase emission of carbon monoxide [29]. Also the concentration of this pollutant may have increased significantly due to the large influx of old and fairly used vehicles imported into the country [38], which is compounded by poor vehicle maintenance culture.

\section{Methodology}

Study Area; The research was conducted in 22 sites within 4 locations in Imo State which include Owerri, Okigwe, Orlu and Egbema as shown in fig.1. Imo State is located in the tropical rainforest zone climate which is dominated by plains with elevation ranging from $50-200 \mathrm{~m}$ above sea level. The annual rainfall is about $2400 \mathrm{~mm}$ to $4000 \mathrm{~mm}$, which is concentrated almost entirely between April and October, with average relative humidity of about $80 \%$ and up to $90 \%$ occurring during the wet season. The maximum air temperature ranges from 28 to $38^{\circ} \mathrm{C}$, while the minimum air temperature range from $19^{0} \mathrm{C}$ to $24^{0} \mathrm{C}[39,40,41]$. 


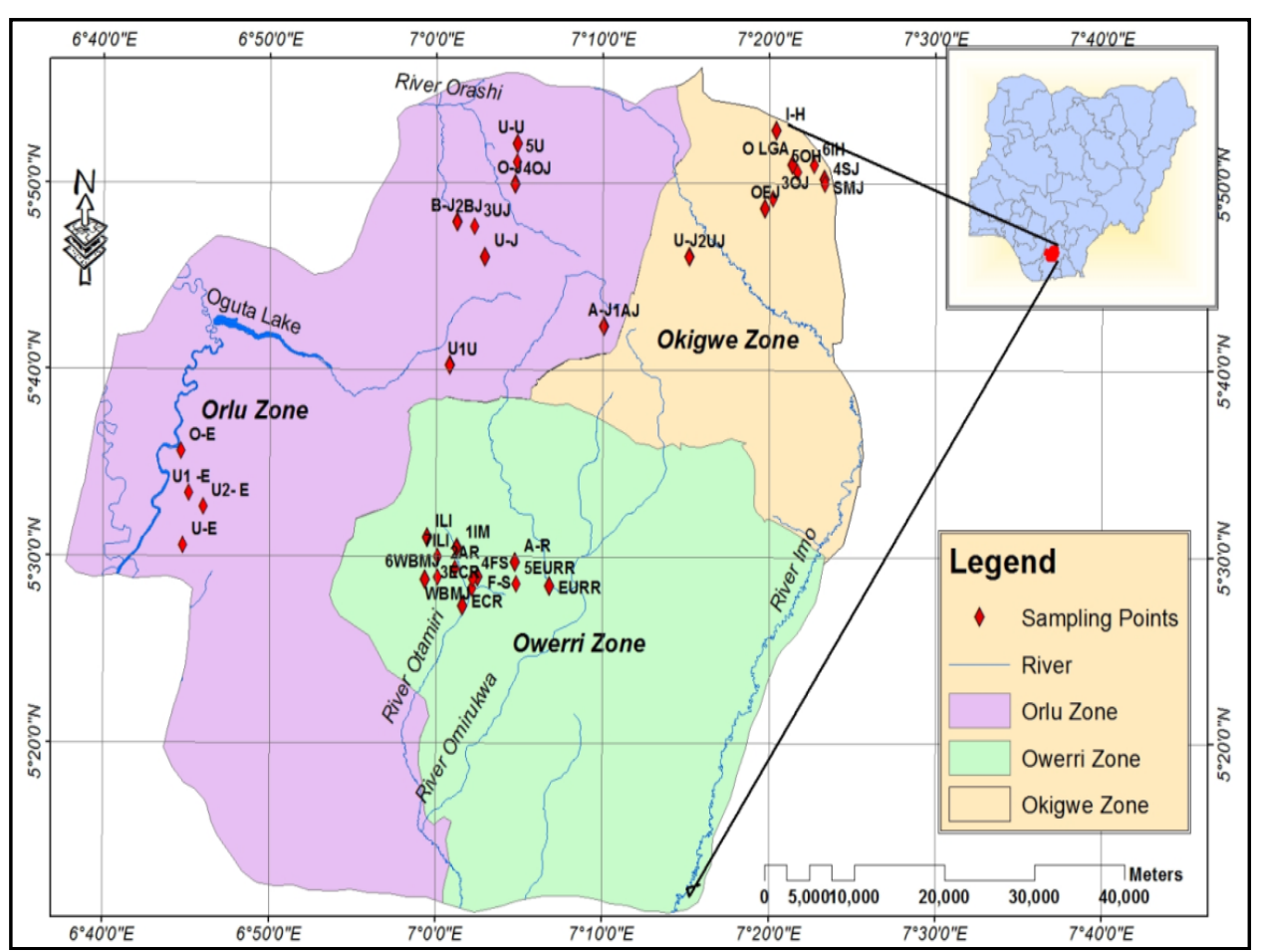

Fig. 1: Map of Imo State showing air quality sampling location

Air Quality Sampling Procedure; Concentration of CO was sampled three times a day (morning, afternoon and evening) with Gasman hand held detector (Crowcon Instruments Ltd, England). Sampling was carried out for six months during dry and wet seasons, between November 2014 and June 2015. The sampling was carried out once a week at each of the 22 air monitoring locations, three times per day, four times a month for a period of six (6) months which was three months in dry season and three months in wet season.

Method of Data Analysis; Data analysis was done using Microsoft excel 2007 and values of all the results from the 22 sampling points in the four locations were recorded as calculated mean values of the air pollutant concentrations in the morning, afternoon and evening hours. The standard deviation (SD) was determined and co-efficient of variation (CV \%) was used to determine variation in the concentration of $\mathrm{CO}$ within and between the seasons. Variation was categorized as little variation $(\mathrm{CV} \%<20)$, moderate variation $(\mathrm{CV} \%=20-50)$ and high variation $(\mathrm{CV} \%>50)$ [42]. Contour and 3-D surface plots of the air pollutant concentration was modeled using Surfer 12 software to further elucidate the variability of $\mathrm{CO}$ in the study locations.

\section{Results and Discussion}

Summary of results of CO concentration obtained from the 22 air quality monitoring sites in the 4 areas are presented in tables 1 - 3 showing, mean, maximum, minimum values, standard deviation and the coefficient of variation (\%). Table 1 is the summary of dry season result, table 2 is the summary of wet season result while table 3 is the summary of a combination of dry and wet season result of $\mathrm{CO}$ obtained from the air quality monitoring sites in the study areas. In each table the coefficient of variation ( $\mathrm{CV} \%$ ) in either morning, afternoon or evening were also presented. Also figure $2-14$ shows the variation of $\mathrm{CO}$ in the study locations as presented with column charts, contour and 3-D surface plots.

The result as shown in table 1 for dry season indicates that in Owerri, the mean concentration of CO ranged from $33.71-40.7,33.57$ - 48.00. 40.57 - $49.43 \mathrm{ppm}$ for morning, afternoon and evening respectively. The result for Okigwe indicates that $\mathrm{CO}(\mathrm{ppm})$ ranged from $30.67-49.17$, 32.50- 47.67 and 34.50 - 49.83 for morning, afternoon and evening respectively. The CO 
Table 1: Summary of dry season CO [ppm] result

\begin{tabular}{llllllllllllll}
\hline & \multicolumn{3}{c}{ Owerri } & \multicolumn{3}{c}{ Okigwe } & \multicolumn{3}{c}{ Orlu } & \multicolumn{3}{c}{ Egbema } \\
\hline & M & A & E & M & A & E & M & A & E & M & A & E \\
Mean & 37.14 & 40.54 & 44.17 & 41.63 & 43.53 & 44.72 & 41.40 & 42.80 & 42.23 & 46.92 & 46.23 & 49.52 \\
Max & 40.71 & 48.00 & 49.43 & 49.17 & 47.67 & 49.83 & 45.40 & 47.00 & 49.00 & 52.00 & 50.00 & 50.50 \\
Min & 33.71 & 33.57 & 40.57 & 30.67 & 32.50 & 34.50 & 35.80 & 35.60 & 38.80 & 44.25 & 39.00 & 47.75 \\
SD & 2.50 & 4.15 & 3.25 & 5.30 & 4.32 & 4.03 & 2.87 & 3.37 & 2.88 & 2.35 & 3.36 & 0.92 \\
CV\% & 6.73 & 10.24 & 7.36 & 12.72 & 9.92 & 9.01 & 6.93 & 7.87 & 2.37 & 5.56 & 7.27 & 1.86 \\
\hline
\end{tabular}

Where $\mathrm{M}=$ morning, $\mathrm{A}=$ afternoon and $\mathrm{E}=$ evening, $\mathrm{SD}=$ standard deviation, $\mathrm{CV} \%=$ co-efficient of variation

(ppm) value for Orlu ranged from $35.80-45.40$ in the morning, $35.60-47.00$ in the afternoon and $38.80-49.00$ in the evening. While in Egbema the CO (ppm) values ranged from $44.25-52.00$, 39.00 and $39.00-50.00$ for morning, afternoon and evening respectively.

The dry season result shown in table 1 also indicates that for Owerri elevated values of CO were observed in the evening when compared with morning and afternoon, the order is $\mathrm{E}>\mathrm{A}>\mathrm{M}$, and the co-efficient of variation is in the order $\mathrm{A}>\mathrm{E}>\mathrm{M}$. While in Okigwe, the order for the observed mean level of $\mathrm{CO}$ is also $\mathrm{E}>\mathrm{A}>\mathrm{M}$, variation is in the order $\mathrm{M}>\mathrm{A}>\mathrm{E}$. In Orlu, the mean $\mathrm{CO}$ level for morning, afternoon and evening is in the order $\mathrm{A}>\mathrm{E}>\mathrm{M}$, with variability in the ranking $\mathrm{A}>\mathrm{M}>\mathrm{E}$. Furthermore, the mean $\mathrm{CO}$ values for Egbema is in the order $\mathrm{E}>\mathrm{M}>\mathrm{A}$, while the co-efficient of variation is also in the order $A>M>E$.

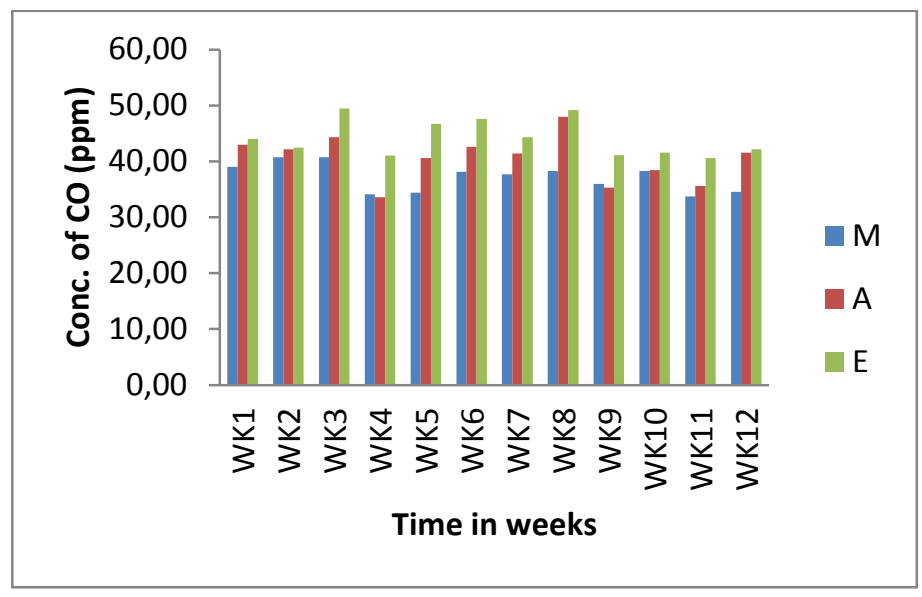

Fig. 2: Variation of CO in Owerri (dry season)

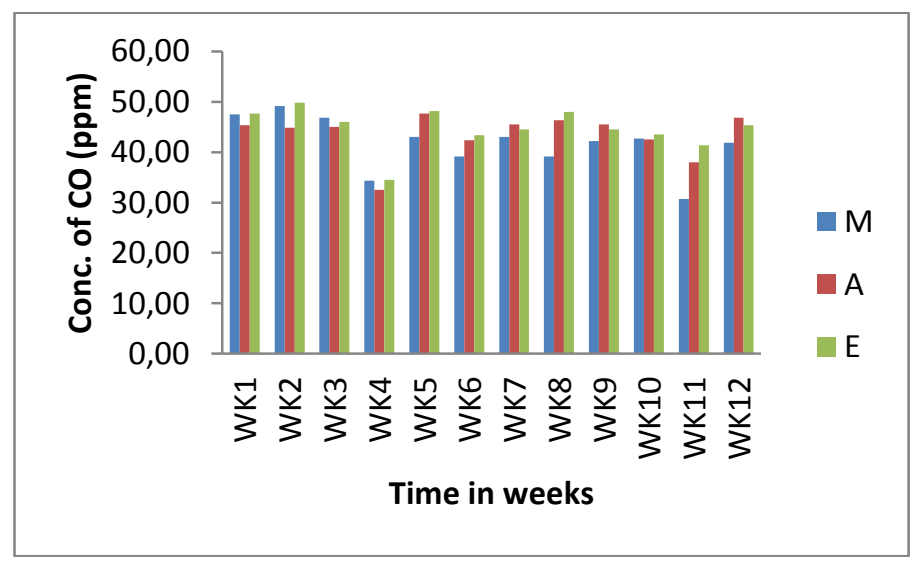

Fig. 3: Variation of $\mathrm{CO}$ in Okigwe (dry season) 
Fig. 2, 3, 4 and 5 shows the variation of $\mathrm{CO}$ level in weeks during the air quality monitoring in the dry season. Fig. 2 indicates that $\mathrm{CO}$ values for Owerri were highest in week 3, 5, 6 and 8. While in Okigwe, fig. 3 indicates that higher values of $\mathrm{CO}$ were observed in week 2, 5, 8 and 12. Also fig. 4 indicates that the level of $\mathrm{CO}$ observed in Orlu in week 6, 7 and 8 were higher than other weeks in dry season. Elevated values of $\mathrm{CO}$ were observed in the afternoon and evening compared to morning hours as shown in fig.1, which could be due to higher vehicular and commercial activities in the area [43, 44]. Also the CO level in Egbema as shown in fig.5 indicates elevated values from week 1 to week 12. This could be attributed to the presence of gas flare starks in this area $[45,46]$. The results shown in Fig. 6 and 7 are the contour and 3-D surface plots of CO in the study locations in dry season. The results indicates that higher concentrations of $\mathrm{CO}$ were observed at Egbema and Okigwe in dry season

Table 2 is the summary of wet season result of $\mathrm{CO}$ values observed in the study locations. The result indicates that in Owerri (wet season) CO (ppm) values ranged from 24.00 - 32.29, 32.71 - 39.00 and $36.57-41.57$ respectively for morning, afternoon and evening. The Owerri mean CO level is in the order $\mathrm{E}>\mathrm{A}>\mathrm{M}$, and variation is in the ranking $\mathrm{M}>\mathrm{A}>\mathrm{E}$. While in Okigwe CO values (ppm) ranged from 29.00 - 38.50, 38.50 - 38.50 and 40.33 - 45.83 for morning, afternoon and evening respectively. The mean $\mathrm{CO}$ value at Okigwe is in the order $\mathrm{E}>\mathrm{A}>\mathrm{M}$, while the coefficient of variation is in the order $\mathrm{M}>\mathrm{A}>\mathrm{E}$. Also the $\mathrm{CO}$ values observed in Orlu ranged from 25.20 - 39.80, 32.80 - 39.80 and 36.40 - 43.00 respectively for morning, afternoon and evening, while the mean value is in the ranking $\mathrm{E}>\mathrm{A}>\mathrm{M}$, and the variation is in the order $\mathrm{M}>\mathrm{A}>\mathrm{E}$. The $\mathrm{CO}(\mathrm{ppm})$ values observed in Egbema ranged from 18.75 - 35.00 in the morning, 26.25 - 40.50 in the afternoon and $36.50-44.25$ in the evening, The mean $\mathrm{CO}$ level is in the order $\mathrm{E}>\mathrm{A}>\mathrm{M}$, while the order of variability is $\mathrm{M}>\mathrm{A}>\mathrm{E}$. In all

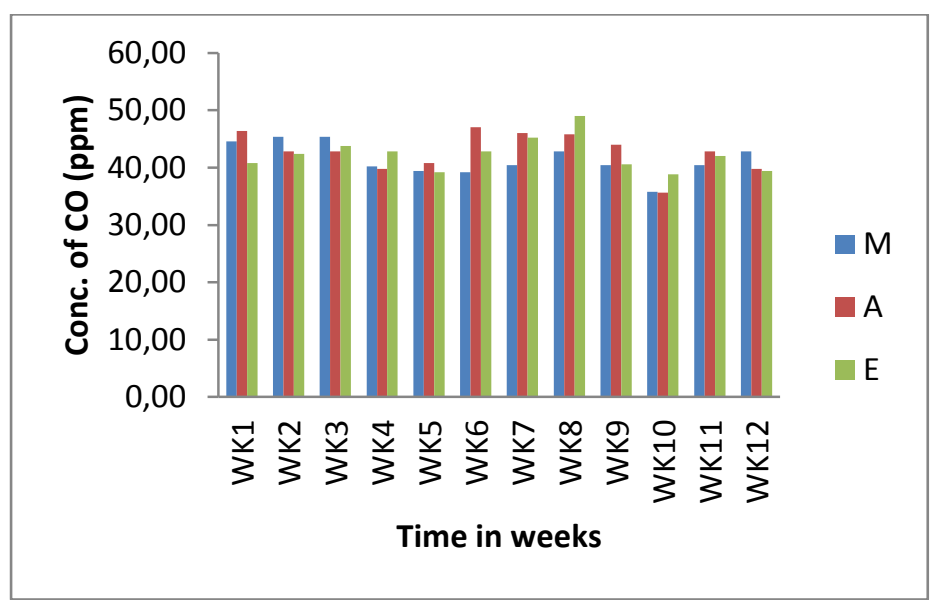

Fig. 4: Variation of CO in Orlu (dry season)

higher variability was observed in the morning even though $(<20 \%)$ is little variation in the variability ranking when compared with afternoon and evening in the wet season.

Again Fig. 8 indicates that lower values of $\mathrm{CO}$ were observed in the morning hours in Owerri in wet season from week $1-12$, and the variation is in the order morning $<$ afternoon $<$ evening. Also fig.9 indicates that there was no significant difference in the level of $\mathrm{CO}$ observed in either morning, afternoon or evening from week $1-12$. While in Orlu as shown in fig. 10, the result indicates that lower value of CO was observed in week 7 in the morning, and elevated values of CO were observed in week $8-12$ in the evening hours. Fig. 11 indicates that in Egbema lower values of $\mathrm{CO}$ were observed in the morning from week $1-2$, while elevated concentrations were observed in week 5, 8, 10 and 12 . 


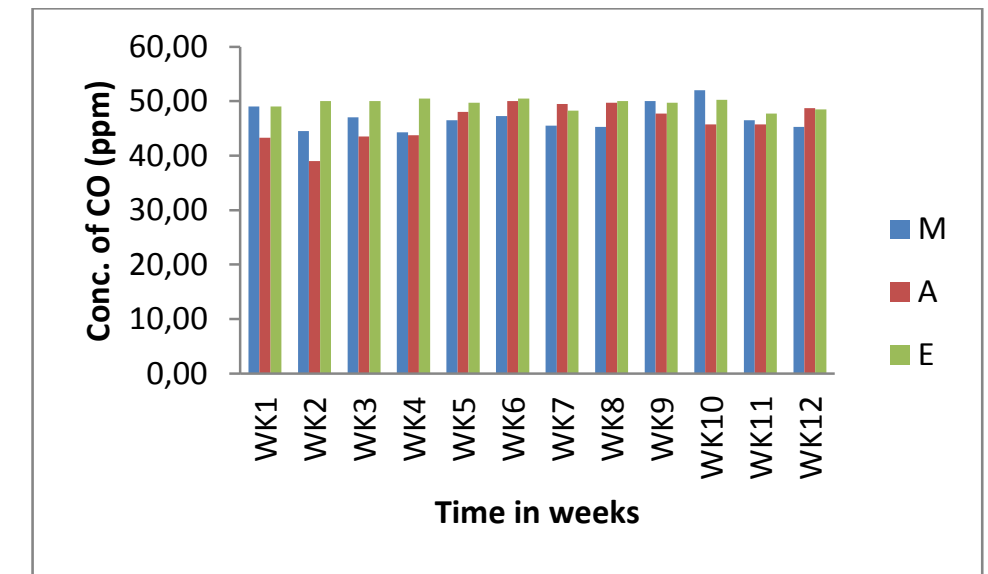

Fig. 5: Variation of CO in Egbema (dry season)

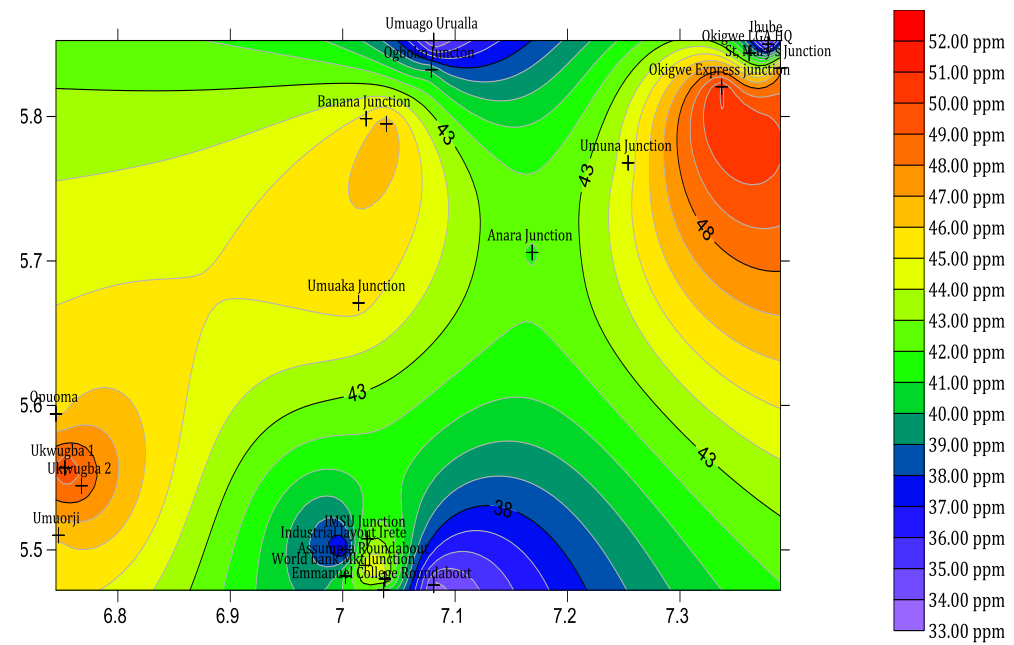

Fig. 6: Contour plot showing variation of $\mathrm{CO}$ in the study area (dry season)
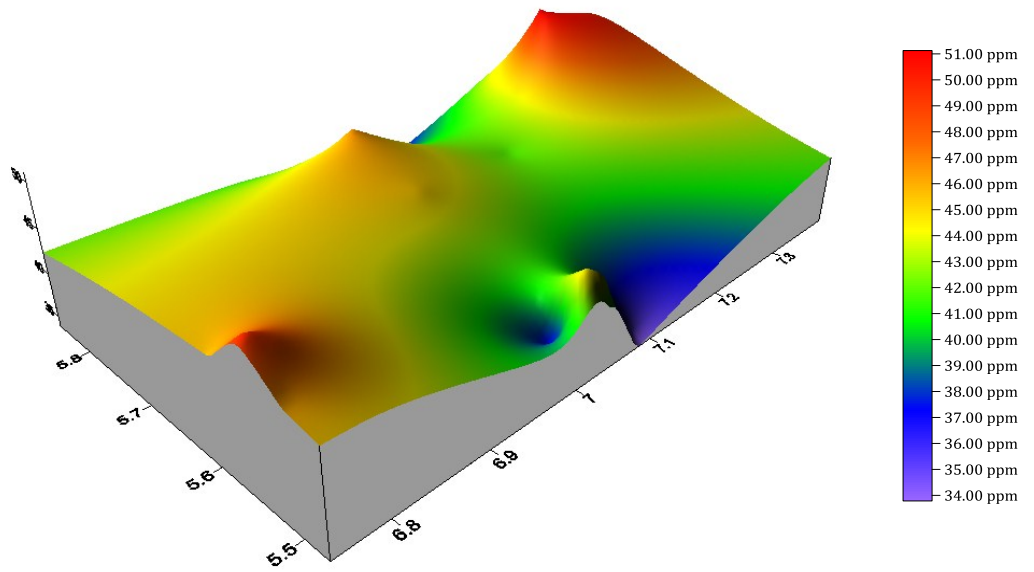

Fig. 7: 3- D surface plot showing variation of CO in the study area (dry season)

Table 2: Summary of wet season CO [ppm] result

\begin{tabular}{lllllllllllll}
\hline & \multicolumn{3}{c}{ Owerri } & \multicolumn{3}{c}{ Okigwe } & \multicolumn{3}{c}{ Orlu } & \multicolumn{3}{c}{ Egbema } \\
\hline & M & A & E & M & A & E & M & A & E & M & A & E \\
Mean & 27.95 & 36.00 & 39.63 & 33.56 & 41.14 & 42.97 & 31.68 & 37.60 & 41.22 & 26.42 & 35.08 & 40.08 \\
Max & 32.29 & 39.00 & 41.57 & 38.50 & 44.33 & 45.83 & 37.40 & 39.80 & 43.00 & 35.00 & 40.50 & 44.25 \\
Min & 24.00 & 32.71 & 36.57 & 29.00 & 38.50 & 40.33 & 25.20 & 32.80 & 36.40 & 18.75 & 26.25 & 36.50 \\
SD & 2.64 & 1.77 & 1.54 & 2.70 & 1.82 & 1.54 & 2.75 & 2.04 & 1.78 & 4.32 & 3.72 & 2.45 \\
CV\% & 9.45 & 4.92 & 3.89 & 8.06 & 4.42 & 3.58 & 8.68 & 5.43 & 4.32 & 16.35 & 10.60 & 6.11
\end{tabular}

Where $\mathrm{M}=$ morning, $\mathrm{A}=$ afternoon and $\mathrm{E}=$ evening, $\mathrm{SD}=$ standard deviation, $\mathrm{CV} \%=$ co-efficient of variation 


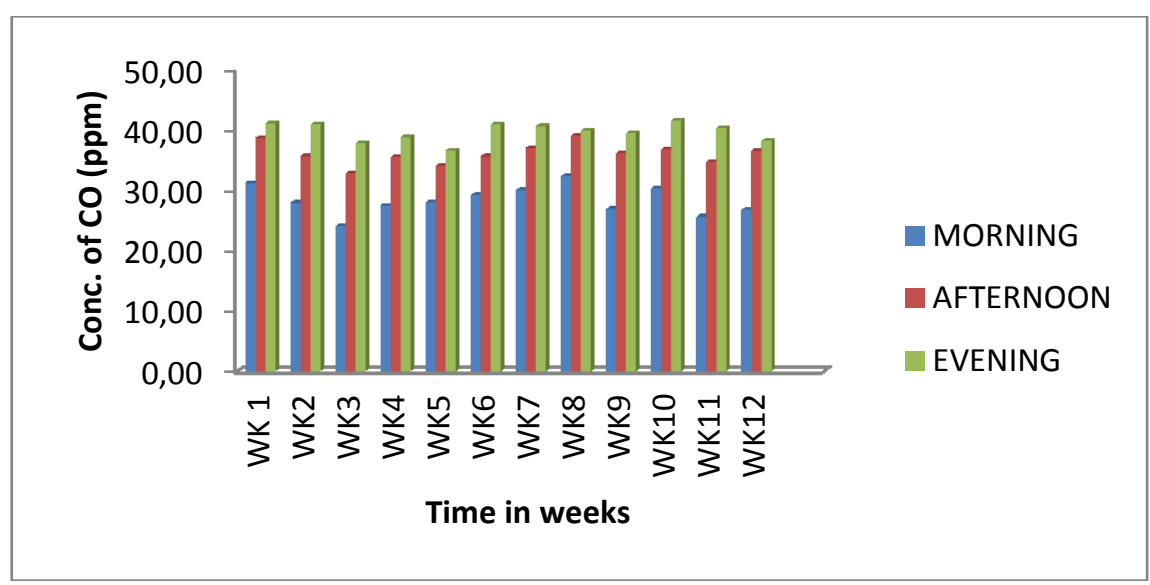

Fig. 8: Variation of CO in Owerri (wet season)

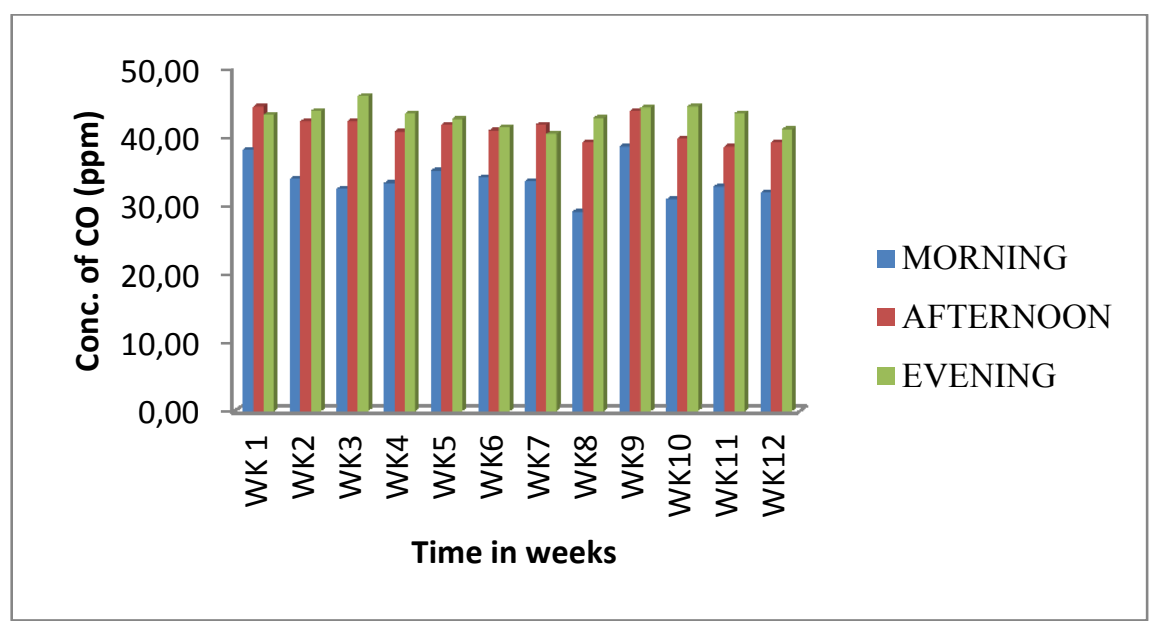

Fig. 9: Variation of CO in Okigwe (wet season)

Furthermore, fig. 12 and 13 are the contour and $3-\mathrm{D}$ surface plot of CO in wet season in the study locations, showing the variation of $\mathrm{CO}$ in the area studied in wet season. The result indicates that elevated values of $\mathrm{CO}$ were observed in Orlu and okigwe when compared with Owerri and Egbema as shown with red colour in the contour and $3-\mathrm{D}$ surface plots.

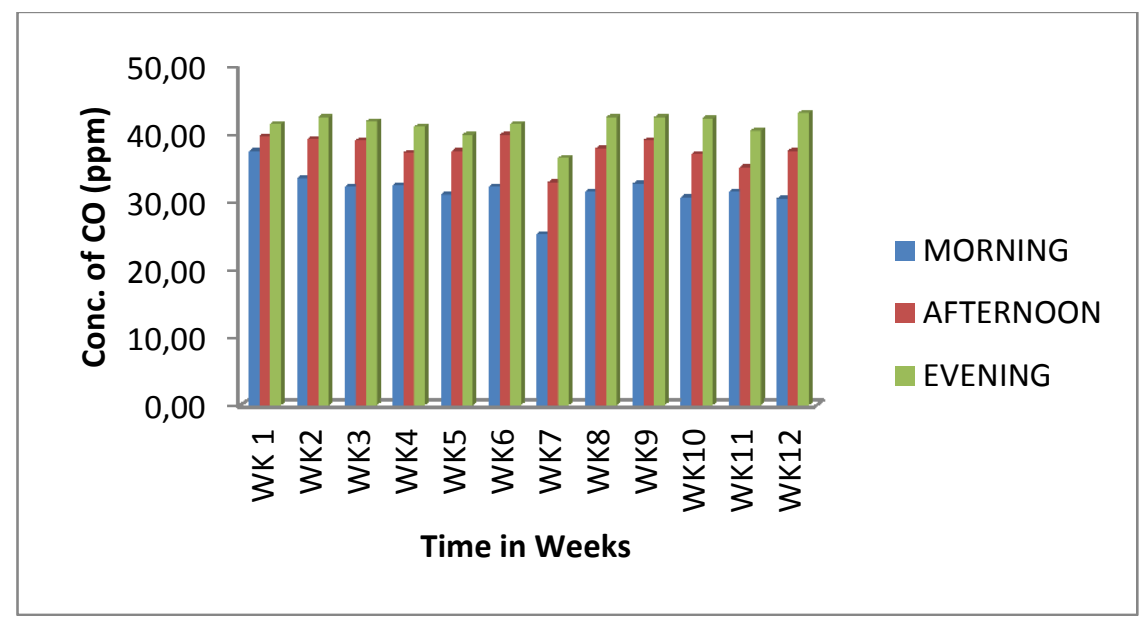

Fig. 10: Variation of $\mathrm{CO}$ in Orlu (wet season) 


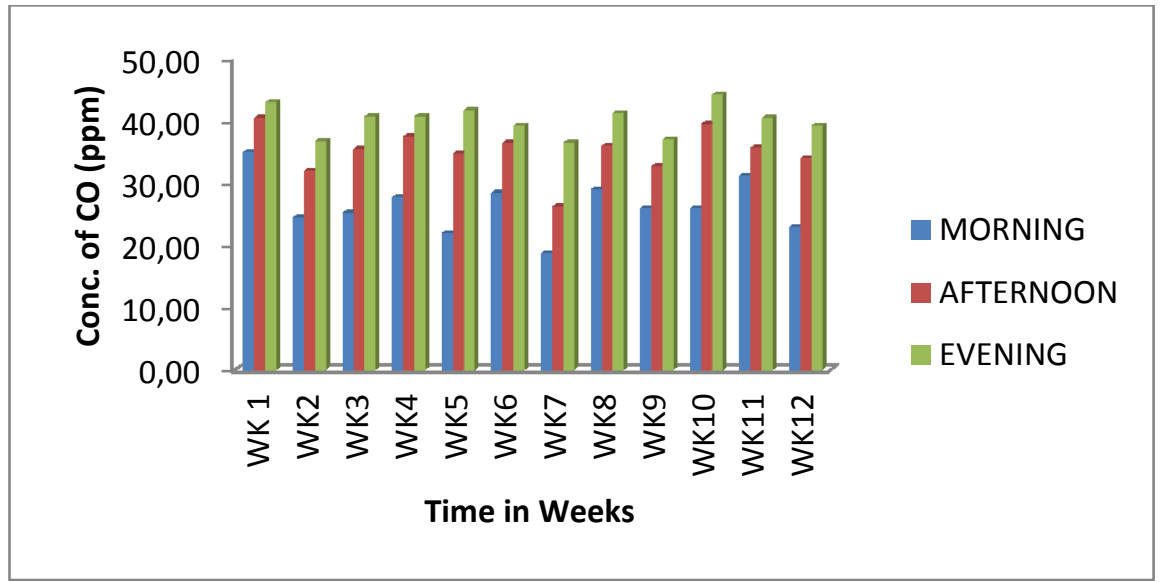

Fig. 11: Variation of CO in Egbema (wet season)

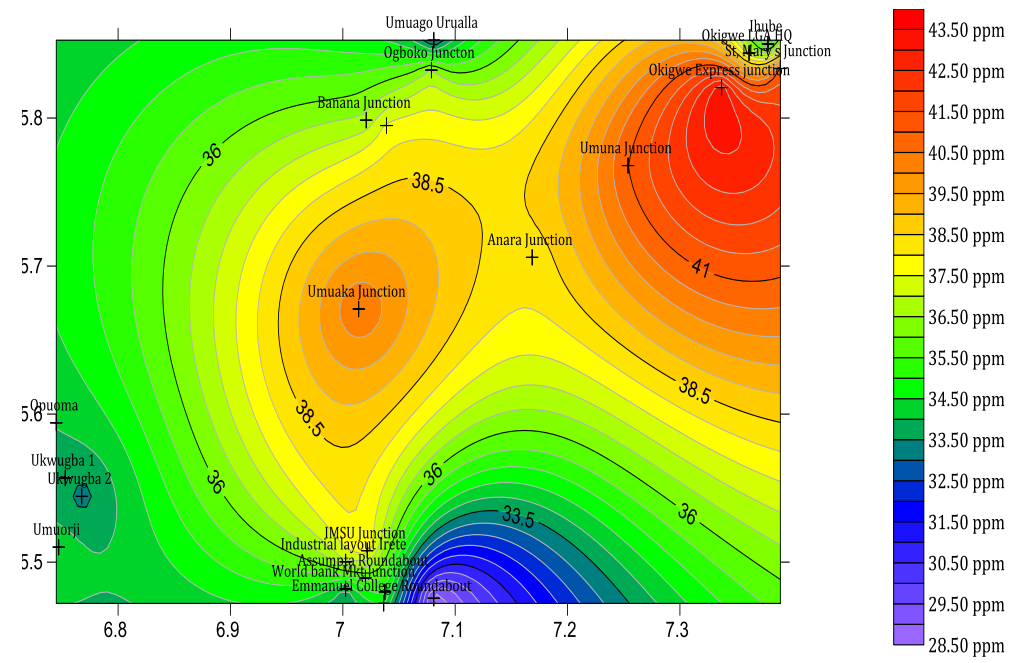

Fig. 12: Contour plot showing variation of $\mathrm{CO}$ in the study area (wet season)
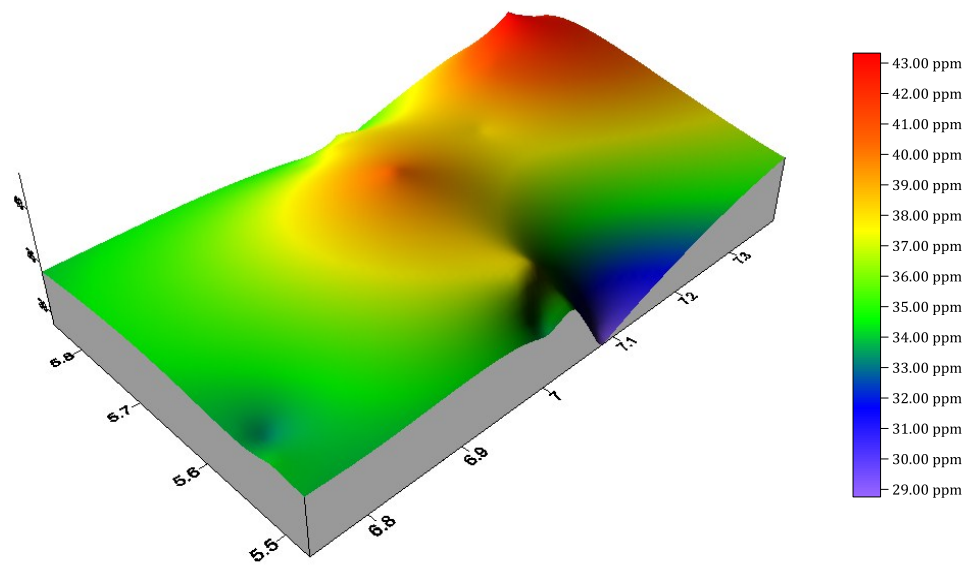

Fig.13: 3- D surface plot showing variation of CO in the study area (wet season)

Table 3: Summary of combined dry and wet season CO [ppm] result

\begin{tabular}{lllllllllllll}
\hline & \multicolumn{3}{c}{ Owerri } & \multicolumn{3}{c}{ Okigwe } & \multicolumn{3}{c}{ Orlu } \\
\hline & M & A & E & M & A & E & M & A & E & M & A & E \\
Mean & 32.71 & 38.23 & 41.90 & 37.59 & 42.33 & 43.85 & 36.54 & 40.20 & 41.73 & 36.67 & 40.66 & 44.80 \\
Max & 40.71 & 48.00 & 49.43 & 49.17 & 47.67 & 49.83 & 45.40 & 47.00 & 49.00 & 52.00 & 50.00 & 50.50 \\
Min & 24.00 & 32.71 & 36.57 & 29.00 & 32.50 & 34.50 & 25.20 & 32.80 & 36.40 & 18.75 & 26.25 & 36.50 \\
SD & 5.12 & 3.91 & 3.40 & 5.82 & 3.46 & 3.12 & 5.67 & 3.81 & 2.40 & 11.01 & 6.67 & 5.15 \\
CV\% & 15.65 & 10.23 & 8.11 & 15.48 & 8.17 & 7.16 & 15.52 & 9.47 & 5.75 & 30.02 & 16.40 & 11.50 \\
\hline
\end{tabular}

Where $\mathrm{M}=$ morning, $\mathrm{A}=$ afternoon and $\mathrm{E}=$ evening, $\mathrm{SD}=$ standard deviation, $\mathrm{CV} \%=$ co-efficient of variation 


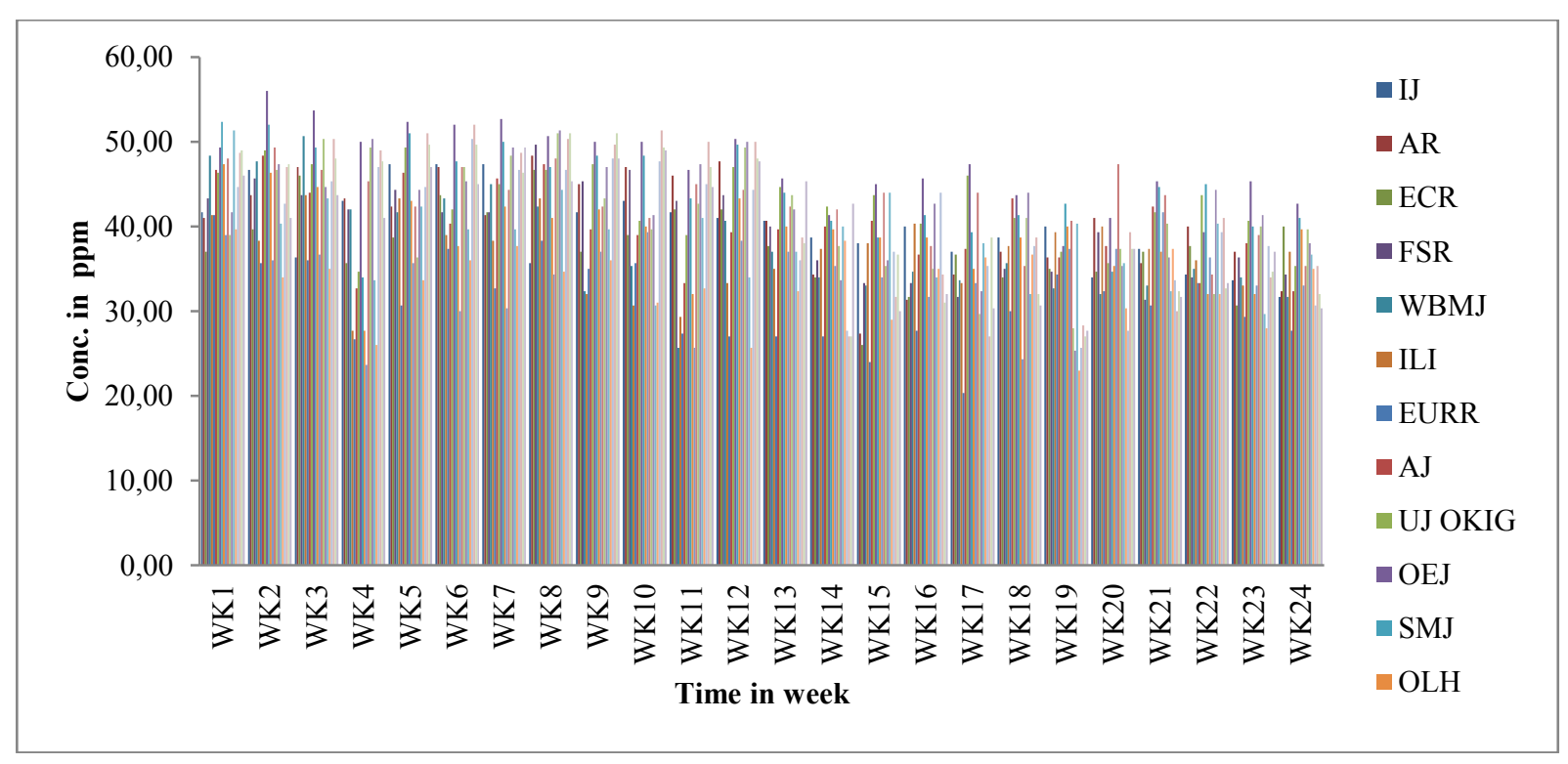

Fig. 14: Variation of $\mathrm{CO}$ in wet and dry season in th air quality monitoring sites

Where Wk1 - WK12 = dry season, WK13 - WK24 = wet season, IJ= IMSU junction, AR= Assumpta roundabout, $\mathrm{ECR}=$ Emmanuel College roundabout, $\mathrm{WBMJ}=$ World Bank market junction, $\mathrm{FSR}=$ Fire service roundabout, $\mathrm{EURR}=\mathrm{Egbu}-\mathrm{Uratta}$ ring road, AJ Anara junction, UJ OKIG.= Umuna junction Okigwe, OEJ $=$ Okigwe express junction, SMJ $=\mathrm{ST}$. Mary's junction, $\mathrm{OLH}=$ Okigwe local government Headquarters, $\mathrm{IH}=$ Ihube, UJ ORL.1= Umuka junction Orlu, Banana junction, UJ ORL.2= Umuna junction Orlu, OJ= Ogboko junction, $U U=$ Umuago Urualla, $\mathrm{UM}=$ Umuorji.U1= UKwugba1, Ukwugba2, $\mathrm{OP}=$ Opuoma

Table 3 is the summary of combined dry and wet season $\mathrm{CO}$ results from the study areas. Some of the results shown in table 3 revealed large standard deviations (SD) which is an indication of the heterogeneous nature of the air samples monitored in the study locations. The results indicates mean value of $32.71,38.23$ and $41.90 \mathrm{ppm}$ in the morning, afternoon and evening respectively in Owerri, while the mean values of $\mathrm{CO}$ (ppm) for Okigwe are 37.59, 42.33 and 43.85 respectively for morning, afternoon and evening. It was also observed that the mean CO (ppm) level in Orlu are 36.54, 40.20 and 41.73 in the morning, afternoon and evening respectively, and that of Egbema are as follows; $36.67,40.66$ and 44.80 respectively for morning, afternoon and evening.

The variability of $\mathrm{CO}$ within dry and wet season as shown in table 3 revealed that in the morning co-efficient of variation is in the order; Egbema $>$ Owerri $>$ Orlu $>$ Okigwe. Egbema showed highest variation (30\%) in the morning. The order of variation in the afternoon is also Egbema $>$ Owerri $>$ Orlu $>$ Okigwe, while the order of variation in the evening is again Egbema $>$ Owerri $>$ Orlu $>$ Okigwe. In both afternoon and evening, Egbema showed highest level of variation in $\mathrm{CO}$ concentration, which is a reflection of the gas flaring activities in this area as earlier noted.

Finally, fig. 14 shows the variation of $\mathrm{CO}$ in dry and wet seasons. The result as shown in fig.14 revealed some level of variation in the concentration of $\mathrm{CO}$ observed in the study areas, as earlier noted, week $1-12$ is dry season while week $13-24$ is wet season. The peaks in fig. 14 from week $1-12$ are more elevated than those of week $13-24$. The conspicuous peaks in week 2, 5, 7 and 12 which were all above $50 \mathrm{ppm}$ is an indication of higher variation of $\mathrm{CO}$ in dry season than in wet season. The mean level of $\mathrm{CO}$ observed in this study was above the Nigerian Ambient Air Quality Standard for CO (10 ppm). Seasonal variation of CO, with highest concentration during the months of August, September and October has been reported [47]. Similarly, a significant difference in the mean concentrations of $\mathrm{CO}$ during the wet, transition and dry seasons has been reported [48]. The higher values of $\mathrm{CO}$ observed in the study areas could be attributed to factors such as higher vehicular traffic [49], presence of three stroke engine tricycles known for incomplete combustion which could emit noxious atmospheric pollutant like CO [29], and combustion of biomass [50]. 


\section{Conclusion}

The seasonal variability of $\mathrm{CO}$ in the ambient environment of the study areas revealed elevated concentration of the air pollutant in all the study locations above permissible limit which calls for concern. Variation in the level of CO was observed in morning, afternoon and evening, including in different weeks and locations. There was also an observable seasonal variability of the atmospheric pollutant. Variability of atmospheric pollutants could be attributed to changes in meteorological and topographical conditions which could change the atmospheric pollution pattern with different locations and time.

Apart from higher vehicular traffic, presence of three stroke engine tricycles known for incomplete combustion and combustion of biomass as being responsible for the observed elevated $\mathrm{CO}$ level. Indiscriminate use of power generators especially the very small generating sets due to erratic supply of electricity from the public electricity distribution could have impact significantly to the observed CO level in the study areas. This is supported by the fact that $\mathrm{CO}$ once emitted could remain in the ambient environment for about four months as earlier noted.

\section{Acknowledgement}

The authors acknowledge the effort of Laboratory Services and Environmental Research Department/UNIDO RAC for Pollution Monitoring and Assessment, Ministry of Environment and Petroleum, Imo State, Nigeria, who provided the air quality monitoring equipment and assisted during the field work.

\section{REFERENCE}

[1] C.M.Wong, N.Vichit-Vadakan, H. Kan and Z. Qian Public Health and air pollution in Asia (PAPA): a multiplicity study of short-term effects of air pollution on mortality. Environ. Health Perspect. 116 (2008) 1195-1202.

[2] H. Kan, B .Chen and C. Hong, Health impact of outdoor air pollution in China: current knowledge and future research needs. Environ Health Perspect 117(5) (2009) 180 - 187.

[3] S.M. Hassan and M. E. Abdullahi, Evalluation of pollutants in ambient air; A case study of Abuja, Nigeria, Int. J. Sci. and Research 2(12) (2012) 1-9.

[4] S.C. Barman, G. C. Kisku, A.H. Khan, T. Ahmed, P Shukla., K. Ahmed, k.A. Singh, V. Gupta, P. Dubey, V. Shukla, R. Kumar and R. P. Mishra Assessment of Ambient Air Quality of Lucknow City during premonsoon, findings of a random survey, presented on World Environment Day, 5th June, 2012 CSIR-Indian Institute of Toxicology Research Mahatma Gandhi Marg, Lucknow, India, (2012). 1-26.

[5] C.A. Pope, M.J. Thun, M. Namboodira, D.W. Dockery, J. S. Evans, Speizer F. E. and C.W. Health Jr., particulate air pollution as a predictor of mortality in a prospective study of US adults, Am. J. Respir. Crit. Care Med., 151 (1995) 669-674.

[6] F. Laden, L.M. Neas, D.W. Dockery and J. Schwartz, Association of fine particulate matter from different sources with daily mortality in six U.S. Cities. Environ. Health Perspect. 108 (2000) 941-947

[7] C.C. Tawari and J.F.N. Abowei, Air pollution in the Niger Delta area of Nigeria, Internat. J. Fisheries and Aquatic Sci., 1(2) (2012) 94-117.

[8] F. C. Ibe, P. C. Njoku, J. I. Alinnor and A.I. Opara, Evaluation of ambient air quality in parts of Imo state, Nigeria, Res. J. Chem. Sci. 6(1) (2016) 41-52.

[9] F. C. Ibe and B. O. Ibe Roof runoff water as source of pollution: A case study of some selected roofs in Orlu metropolis, Imo State, Nigeria. International Letters of Natural Sciences, 50 (2016), $53-61$. 
[10] P.C. Njoku and F. C. Ibe, Heavy metal accumulation in electronic technicians in Owerri. JCSN, 34(1) (2009) 1- 4.

[11] B. Brunekreef and S.T. Holgate, Air Pollution and Health, Lancet, 360(9341) (2002) 12331242.

[12] S.M. Al-Salem and W.S. Bouhamrah, Ambient concentrations of benzene and other VOC's at typical industrial Sites in Kuwait and their Cancer Risk Assessment, Research Journal of Chemistry and Environment, 10(3) (2006) 42-46.

[13] F.C. Ibe, P.C. Njoku, J.I. Alinnor and A.I. Opara, Spatial Variation of $\mathrm{NO}_{2}$ and $\mathrm{SO}_{2}$ in the ambient environment of Imo State, Nigeria, IJSET,5(1) (2016) 33 - 46.

[14] J. A. Fisher, S. R. Wilson, G. Zeng, J. E. Williams, L. K. Emmons, R. L. Langenfelds, P. B. Krummel, and L. P. Steele, Seasonal changes in the tropospheric carbon monoxide profile over the remote Southern Hemisphere evaluated using multi-model simulations and aircraft observations Atmos. Chem. Phys., 15 (2015) 3217 - 3239.

[15] S. Ocak and F. S. Turalioglu,Effect of meteorology on the atmospheric concentrations of traffic- related pollutants in Erzurum, Turkey, J. Int. Environmental Application \& Science, 3(5) (2008) 325-335.

[16] DEFRA (Department of Environment, Food and Rural Development) (2013) Effects of air pollution, DEFRA, UK http://airquality.defra.gov.uk, accessed 23/10/2015.

[17] S.E Manahan, Fundamentals of environmental chemistry CRC press LLC, Boca Raton, 2001.

[18] G. Myhre, D. Shindell, F.M. Bréon, W. Collins, J. Fuglestvedt, J. Huang, D. Koch, J.F.Lamarque, D. Lee, B. Mendoza, T. Nakajima, A. Robock, G. Stephens, T. Takemura, and H. Zhang, Anthropogenic and natural anthropogenic and natural radiative forcing, in climate change 2013: The Physical science basis. Contribution of working group to the fifth assessment report of the intergovernmental panel on climate change, in: T. Stocker, D. Qin, G.K. Plattner, M. Tignor, S. Allen, J. Boschung, A. Nauels, Y. Xia, V. Be, and P. Midgley, (Eds) chap. 8, Cambridge University Press, Cambridge, UK and New York, 2013

[19] V.P. Aneja, A. Agarwa., P.A. Roelle, S.B Philips., Q. Tong, N. Watkins, D.Yablonsky, Measurements and analysis of criteria pollutants in New Delhi, India. Environment International, 27 (2001) 35-42.

[20] S. H. Cadle, B. E. Croes, F. Minassian, M. Natarajan, E. J. Tierney and D. R. Lawson, Realworld vehicle emissions: A summary of the Thirteenth Coordinating Research Council on - road Vehicle Emissions Workshop. Journal of the Air and Waste Management Association 54(1) (2004) $18-23$.

[21] S.C. Bhatia, Environmental chemistry, CBS publishers and distributors, New Delhi, 2002.

[22] T. Holloway, H. Levy and P. Kasibhathala, Global distribution of carbon monoxide, Geophysical research 105 (2000) 12123 - 12147.

[23] J. Wright, Environmental chemistry, Routledy (Taylor \& Francis Group) London, 2003.

[24] Hydrogen sulphide, World Health Organization, Environmental Health criteria 2005, No 19, WHO Geneva. http://www.who.int/ipcs/publications/cicad/en/cicad53.pdf, accessed 15/12/15.

[25] V. S. Balogun, O. O. I. Orimoogunje, An assessment of seasonal variation of air pollution in Benin City, Southern Nigeria, Atmospheric and Climate Sciences, 5 (2015) 209-218.

[26] E.E. Ukpebor, J.E. Ukpebor, F. Eromomene, J.I. Odiase and D. Okoro, Spatial and Diurnal Variations of Carbon Monoxide (CO) Pollution from Motor Vehicles in an Urban Space. Polish Journal of Environmental Studies, 19 (2010) 817-823. 
[27] S.V. Mikhailyuta, O.V. Taseiko and A.A. Lezhenin, Seasonal variations of the air pollutant concentrations for Krasnoyarsk non-uniform urban territory, Bull. Nov. Comp Center, Num.Model. in Atmosph., 11(2007) 25 - 42.

[28] C. O. Ogba and B. P. Utang, Air pollution climatology in spatial planning for sustainable development in the Niger Delta, Nigeria, TS 1D - Environment and land use planning, FIG working week 2009 Surveyor's Key Role in Accelerated Development, 3-8 May, 2009, Eilat, Israel. https://www.fig.net/resources/proceedings/ fig_proceedings/ fig2009/ papers/ ts01d/ts01d_ogba utang_3202.pdf accessed 19/12/15.

[29] B. Sengupta (Ed.), Guidelines for ambient air quality monitoring, National ambient air quality monitoring series, NAAQMS. Central pollution control board, Parivesh Bhawan, East Ajun Nagar, Delhi, April, 2003, http://www.cpcb.nic.in/newitems/7.pdf accessed 20/03/2014.

[30] D. Kim, J. Lee, C. K. Song, S. Kim, Y. Ma, K. Lee, J. Cha and S. Lee, Temporal and spatial distribution of tropospheric $\mathrm{NO}_{2}$ over Northeast Asia using OMI data during the years 2005-2010 Atmospheric Pollution Research 6 (2015) 768-777.

[31] S. A. Abdul-Wahab and W. S. Bouhamra, Diurnal variations of air pollution from motor vehicles in residential area, Int. J. Environ. Studies, 61(1) (2004) 73 - 98.

[32] P.W. Summers, The seasonal, weekly and daily cycles of atmospheric smoke contents in Central Montreal, J. Air Poll. Contr. Asso.,18(8) (1968), 123 - 135.

[33] S. h. Nagendra and M. Khare, Diurnal and seasonal variations of carbon monoxide and nitrogen dioxide in Delhi city, Int. J. Environment and pollution,19(1) (2003) 75 - 95.

[34] P. J. Temple and O. C. Taylor, World-wide ambient measurements of peroxyacetyl nitrate (PAN) and implications for plant injury, Atmospheric Environment, 17(8) (1983) 1583 - 1587.

[35] O. Odeyemi and O.A. Ogunseitan, Petroleum Industry and its Pollution Potential in Nigeria. Oil and Petroleum Pollution, Applied Science, 2 (1985) 223-228.

[36] NNPC, (Nigeria National Petroleum Corporation) Nigerian National Petroleum Coperation, Monthly Petroleum Information, Lagos, Nigeria, September, 531984.

[37] FRN (Federal Republic of Nigeria), Official Gazette, Legal Notice on publication of the details of the Breakdown of the National and State Provisional total, 2006 Census.Federal Republic of Nigeria Official Gazette, Government Notice No. 21, Lagos - Vol. 94. 15th May, 2007,

[38] I. F. Abam and G. O. Unachukwu, Vehicular emission and air quality standards of Nigeria, European Journal of of Science Research, 34(4) (2009), 550 - 560.

[39] E.A Ubuoh and S. M.O. Akhionbare, Effect of pig production on the ambient air quality of Egbeada in Mbaitoli LGA of Imo State, Nigeria, J. Sci. and Multidisciplinary Research, 3 (2011) 816.

[40] U.K. Okoro, W. Chen, T.C. Chineke and O.K. Nwofor, Recent monsoon rainfall characteristics over the Niger Delta Region of Nigeria: A causal link, IJSET, 3(2) (2014) 634 - 651.

[41] U.K. Okoro, W. Chen, T.C. Chineke and O.K. Nwofor, Comparative analysis of gridded datasets and gauge measurements of rainfall in the Niger Delta region of Nigeria, Research Journal of Environ. Sci., 8(7) (2014) 373-390.

[42] E. N. Verla, A. W. Verla and L. Ugwulor, Seasonal variation of heavy metals in playgrounds of public schools within Owerri Metropolis, Imo State, Nigeria, International Letters of Chemistry, Physics and Astronomy, 50 (2015) 61-70.

[43] L. Johnson, M. Jamriska, L. Morawska and L Ferreira, Vehicle emissions in Australia: from monitoring to modelling, Advances in Transport, Urban Transport VI: Urban Transport and the Environment for the 21st Century, 6 (2000) 469-478. 
[44] S. J. Ojolo, S. A. Oke, R. R. Dinrifo and F. Y. Eboda, A survey on the effects of vehicle emissions on human health in Nigeria, Journal of Rural and Tropical Public Health 6 (2007) 16 23.

[45] J. N. Egwurugwu, A. Nwafor, P. Nwankpa, O. J. Olorufemi and J. E. Okwara, Prolong gas flaring and water quality in Obiakpu, Egbema Imo State Nigeria, International Research Journal of Environmental Science, 2(4) (2013) 1-5.

[45] E. B. Audu Gas Flaring: A catalyst to global warming in Nigeria, International Journal of Science and Technology 3(1) (2013) 6 - 10.

[47] A. de Souza, F. Aristones, G. B. M. Silva, W. A. Fernandes and C. Braga, TemporalVariation of the Concentration of Carbon Monoxide in the Center West of Brazil, Atmospheric and Climate Sciences, 4 (2014) 563-568.

[48] V. E. Weli and J.O. Ayoade, Seasonal analysis of atmospheric pollutants concentrations in urban and rural land use areas of Rivers State, Nigeria, International Journal of Environment and Pollution Research 2(3) (2014) 1-16.

[49] F.A. Akeredolu, A.F. Oluwole, E.A. Beliku andO.J. Ogunsola, Modelling of carbon monoxide concentration for motor vehicles travelling near roadway intersections in Lagos, Nigeria' in Lagos, Nigeria' the 2nd int'l conference on air pollution. Part 2 (2), Barcelona, 1994.

[50] A.M. Piotrowska, W. Kordylewski, J. Ciolek and K. Moscicki, Characterization of air pollutants emitted from biomass combustion in small retort boiler, Environ. Prot. Eng. 36(2) (2010) $123-131$. 